\title{
Erratum to: A Comparative Study on Activated Carbons Derived from a Broad Range of Agro-industrial Wastes in Removal of Large-Molecular-Size Organic Pollutants in Aqueous Phase
}

\author{
G. J. F. Cruz • L. Matějová • M. Pirilä • K. Ainassaari • \\ C. A. Canepa • J. Solis • J. F. Cruz • O. Šolcová • \\ R. L. Keiski
}

Published online: 29 October 2015

(C) Springer International Publishing Switzerland 2015

\section{Erratum to: Water Air Soil Pollut \\ DOI 10.1007/s11270-015-2474-7}

The original publication of this article unfortunately contained errors. The units of two entries in "Abbreviations" and "Greek letters" are wrong.

In Abbreviations, $\mathrm{k} 2$, the unit should have been "(g/mg.h)" instead of "mg h)/mg h)". Also in

The online version of the original article can be found at http://dx. doi.org/10.1007/s11270-015-2474-7.

G. J. F. Cruz · C. A. Canepa

Facultad de Ciencias Agrarias, Laboratorio de Análisis Ambiental, Universidad Nacional de Tumbes, Av. Universitaria s/n, Campus Universitario, Pampa Grande, Tumbes, Peru

L. Matějová $(\bowtie) \cdot$ O. Šolcová

Department of Catalysis and Reaction Engineering, Institute of Chemical Process Fundamentals of the CAS, v. v. i, Rozvojová 135, 16502 Prague, Czech Republic

e-mail: matejova@icpf.cas.cz

M. Pirilä $\cdot$ K. Ainassaari $\cdot$ R. L. Keiski

Faculty of Technology, Environmental and Chemical Engineering, University of Oulu, P.O. Box 4300, 90014 Oulu, Finland

J. Solis

Facultad de Ciencias, Laboratorio de Materiales Funcionales, Universidad Nacional de Ingeniería, Av. Tupac Amaru 210, Lima 25, Peru

J. F. Cruz

Departamento de Ingeniería Química, Universidad Nacional de Piura, Campus Universitario s/n, Urb. Miraflores, Piura, Peru

Abbreviations, mAC, the unit should have been "(g)", instead of "h))".

In Greek Letters, $\rho \mathrm{Hg}$ and $\rho \mathrm{He}$, the unit should have been " $\left(\mathrm{g} / \mathrm{cm}^{3}\right)$ " instead of " $\left.\left.\mathrm{mg} \mathrm{h}\right) / \mathrm{cm}^{3}\right)$ ".

The corrected Abbreviations and Greek letters list is provided here.

\section{Abbreviations}

$S_{\mathrm{BET}}$

$S_{\text {meso }}$

$V_{\text {intruse }}$

$V_{\text {micro }}$

$V_{\text {net }}$

$C_{\text {modif }}$

$C_{0}$

$C_{\mathrm{t}}$

$H$

$k_{2}$

$m_{\mathrm{AC}}$ specific surface area calculated according to the classical BET theory $\left(\mathrm{m}^{2} / \mathrm{g}\right)$ mesopore surface area calculated according to the modified BET equation $\left(\mathrm{m}^{2} / \mathrm{g}\right)$

pore volume determined by high-pressure mercury intrusion $\left(\mathrm{cm}^{3} / \mathrm{g}\right)$

micropore volume calculated according to the modified BET equation $\left(\mathrm{mm}^{3}{ }_{\mathrm{liq}} / \mathrm{g}\right)$ net pore volume determined from the nitrogen adsorption isotherm at maximum $p / p_{0}(\sim 0.9900)\left(\mathrm{mm}^{3}{ }_{\mathrm{liq}} / \mathrm{g}\right)$ adsorption constant in the first layer calculated according to the modified BET equation $(-)$

initial concentration of adsorbate in solution (mg/l)

adsorbate concentration in solution at time $t(\mathrm{mg} / \mathrm{l})$

initial adsorption rate as $q_{\mathrm{t}} / t$ approaches 0 (mg/g min) pseudo-second-order rate constant (g/mg. h) mass of activated carbon $\mathrm{mg}(\mathrm{g})$ 
$q_{\mathrm{e}} \quad$ calculated equilibrium adsorption capacity $(\mathrm{mg} / \mathrm{g})$

$q_{\mathrm{t}} \quad$ amount adsorbed at time $t(\mathrm{mg} / \mathrm{g})$

$t \quad$ adsorption time (h)

$V \quad$ total volume of solution (l)

CPH-RM cocoa pod husk raw material

CH-RM coffee husk raw material

CC-RM corncob raw material

MSIP-RM internal part of the mango pit (mango seed) raw material

MSEP-RM external part of the mango pit (mango seed husk) raw material
CPH-AC cocoa pod husk-derived activated carbon

$\mathrm{CH}-\mathrm{AC}$ coffee husk-derived activated carbon

$\mathrm{CC}-\mathrm{AC} \quad$ corncob-derived activated carbon

MSIP-AC internal part of the mango pit (mango seed)-derived activated carbon

MSEP-AC external part of the mango pit (mango seed husk)-derived activated carbon

\section{Greek Letters}

$\varepsilon \quad$ porosity of material (\%)

$\rho_{\mathrm{Hg}} \quad$ bulk density of material $\left(\mathrm{g} / \mathrm{cm}^{3}\right)$

$\rho_{\mathrm{He}} \quad$ skeletal density of material $\left(\mathrm{g} / \mathrm{cm}^{3}\right)$ 